\title{
Fertility of sheep given antisera to steroids during anoestrus
}

\author{
R. B. Land, Marjorie Fordyce, I. K. Gauld, B. A. Morris* and R. Webb
}

A.R.C. Animal Breeding Research Organisation, West Mains Road, Edinburgh EH9 3JQ and

*Department of Biochemistry, University of Surrey, Guildford, Surrey, U.K.

\begin{abstract}
Summary. The incidence of oestrus (6/46) and ovulation (14/46) in ewes given antisera to androstenedione, oestrone, oestradiol and testosterone either separately or as a mixture of these sera at the time of treatment with progestagen sponges alone or progestagen sponges followed by LH-RH was similar to that of control ewes (2/13 and $6 / 13$ respectively). The number of corpora lutea $(C L)$ recorded for those ewes that did ovulate was, however, greater in the antiserum-treated ewes $(22 \mathrm{CL} / 14$ ewes) than in the controls $(6 \mathrm{CL} / 6$ ewes) at the first ovulation after sponge withdrawal. This superiority persisted to the second ovulation $(53 \mathrm{CL} / 42$ treated ewes compared to $13 \mathrm{CL} / 13$ controls). The results for groups treated with antisera did not differ amongst themselves.
\end{abstract}

\section{Introduction}

Passive immunization of sheep to gonadal steroids during the breeding season may raise both the ovulation rate (Pathiraja, 1982) and the number of lambs born (Land, Morris, Baxter, Fordyce \& Forster, 1982). A possible mechanism of such an effect is that the antisera interfere with the equilibria between gonadotrophin release and gonadal activity. Variation in such equilibria is however not only a characteristic of variation in ovulation rate but also of variation in fertility; on long days LH release is hypersensitive to the negative feedback effects of oestrogen (Legan, Karsch \& Foster, 1977). Follicular oestrogen apparently restricts the rate of LH pulses to a frequency below that required for follicle maturation. The stimulation of an ovulatory LH discharge with LH-RH may induce ovulation but the function of the resultant corpora lutea is impaired (Haresign \& Lamming, 1978); the simulation of a tonic LH pulse pattern characteristic of the follicular phase of the oestrous cycle induces follicle maturation (McNeilly, O'Connell \& Baird, 1982). We report therefore the treatment of sheep with antisera to gonadal steroids during anoestrus and their subsequent reproductive function.

\section{Materials and Methods}

Animals. Mature Welsh Mountain ewes were studied at the ABRO farm, Blythbank, Tweeddale.

Antisera. The production of the antisera used and the measurement of their titres has been described by Land et al. (1982). Briefly, the titre was measured by radioimmunoassay (Abraham, 1975 ) and expressed as the final dilution of antiserum in the reaction volume that bound $50 \%$ of the labelled steroid added.

Treatment and observations. The sheep were subdivided at random to 6 groups; those in one group were kept as untreated controls (Group C); ewes in 4 groups were each treated with an 
antiserum raised against one of the steroids androstenedione (Group A), oestrone (Group $E_{1}$ ), oestradiol (Group $\mathrm{E}_{2}$ ) or testosterone (Group T), and those in Group M were given a mixture of all four antisera. Control ewes were not given sera so that the possibility that antisteroid sera may affect the reproductive activity of anoestrous ewes could be tested specifically. The aim was to allocate 10 or 11 ewes to each group, but two additional animals were available to increase the number in the control group to 13 .

The dose of antiserum was chosen such that it would induce the ovulation of additional follicles if given during the breeding season, i.e. $74 \mathrm{ml}$ anti-androstenedione serum (titre $1: 102000) ; 12 \mathrm{ml}$ anti-oestrone serum (titre $1: 750000$ ); $7.5 \mathrm{ml}$ anti-oestradiol serum (titre $1: 810000$ ); and $17 \mathrm{ml}$ antitestosterone serum (titre 1:540000). Each sheep in Group M was given 25\% of each of the individual serum doses.

Intravaginal progestagen sponges (Chronogest; Intervet) were inserted in all sheep for a period of 9 days from the time of treatment with antisera ( $27 \mathrm{July}$ ) so that oestrus would not be prejudiced by the lack of progestagen priming. Sponges were withdrawn at $21: 00 \mathrm{~h}$ on the 9 th day (Day 0 ) and the ewes were examined twice daily from the following morning for oestrus; vasectomized rams were introduced to the ewes, and those standing to be mated by the rams were recorded as having shown oestrus. Ewes showing oestrus were mated with rams morning and afternoon or afternoon and the following morning. From Day 4 to Day 22, the ewes were run with keeled fertile rams and marked ewes were recorded. LH-RH agonist ( $8 \mu \mathrm{g}$ Hoe 766 ; Hoechst) was given i.v. to half the animals in each group at 10:00 h on the second day after sponge withdrawal (i.e. after $37 \mathrm{~h}$ ) to supplement postive feedback.

The numbers of fresh (red) corpora lutea on each ovary were recorded 3 or 4 days before sponge insertion, and then 8 or 9 and 25,30 or 33 days after sponge withdrawal (i.e. in the 1 st and 2 nd potential oestrous cycles). The ovaries were examined by laparoscopy; the day of laparoscopy was at random within the restriction that animals which did show oestrus were examined within 3-13 days after that oestrus. Samples of blood were collected at $4 \mathrm{~h}$ after the injection of LH-RH agonist on Day 2 for the measurement of LH, and on Days 7 and 13 for the measurement of progesterone.

Unfortunately, 6 of the ewes died (4 in Group T, 2 in Group M). The time of death, post-mortem reports and subsequent bacteriological examinations of the sera indicated that this was due to bacterial contamination of the anti-testosterone serum. There were therefore only 6 sheep in Group $\mathrm{T}$ and 9 in Group $\mathrm{M}$.

\section{Hormone assays}

Concentrations of $\mathrm{LH}$ in peripheral plasma were determined in duplicate by a radioimmunoassay described previously (Carr \& Land, 1975; Land, Carr, McNeilly \& Preece, 1980). LH concentrations are expressed in terms of NIH-LH-S18. All samples were measured in one assay, thus avoiding between-assay variation. The sensitivity of the LH assay was $0.3 \mathrm{ng} / \mathrm{ml}$ and the intraassay coefficient of variation was $4 \cdot 1 \%$.

Progesterone was measured in samples of plasma by the method described by McNeilly, Hunter, Land \& Fraser (1981). All samples were measured in one assay. Intra-assay coefficient of variation was $8.7 \%$ and the sensitivity was $10 \mathrm{pg} /$ tube.

\section{Results}

Only 8 of the 59 sheep studied showed oestrus during the first few days after sponge withdrawal, 4 on Day 2, 4 on Day 3 (Table 1); none of the antisera treatments increased the proportion of ewes mated at this time. Equally, none of the antisera given increased the proportion of ewes which ovulated; 6 of 13 control ewes ovulated compared with 14 of 46 treated with anti-steroid sera. Nine of the treated and 5 of the control animals ovulated without showing oestrus. 
Table 1. The number of sheep showing oestrus, ovulating and with one or two fresh corpora lutea in the first and second potential oestrous cycles in groups injected with antisera to androstenedione (A), oestrone $\left(E_{1}\right)$, oestradiol $\left(E_{2}\right)$, testosterone $(T)$, a mixture (M) and of untreated controls (C)

\begin{tabular}{|c|c|c|c|c|c|c|c|c|c|}
\hline \multirow{2}{*}{$\begin{array}{l}\text { Oestrous } \\
\text { cycle }\end{array}$} & \multirow[b]{2}{*}{ LH-RH } & & \multicolumn{6}{|c|}{ Group } & \multirow[b]{2}{*}{ Total } \\
\hline & & & A & $\mathrm{E}_{1}$ & $\mathrm{E}_{2}$ & $\mathbf{T}$ & $\mathbf{M}$ & C & \\
\hline 1 & - & $\begin{array}{l}\text { No. of ewes } \\
\text { Oestrus } \\
\text { Ovulation } \\
\text { No. of CL-1 } \\
\quad-2\end{array}$ & $\begin{array}{l}5 \\
0 \\
1 \\
1 \\
0\end{array}$ & $\begin{array}{l}5 \\
1 \\
4 \\
2 \\
2\end{array}$ & $\begin{array}{l}5 \\
1 \\
1 \\
1 \\
0\end{array}$ & $\begin{array}{l}3 \\
0 \\
1 \\
0 \\
1\end{array}$ & $\begin{array}{l}3 \\
0 \\
0 \\
0 \\
0\end{array}$ & $\begin{array}{l}5 \\
1 \\
3 \\
3 \\
0\end{array}$ & $\begin{array}{r}26 \\
3 \\
10\end{array}$ \\
\hline 1 & + & $\begin{array}{l}\text { No. of ewes } \\
\text { Oestrus } \\
\text { Ovulation } \\
\text { No. of } \mathrm{CL}-1 \\
\quad-2\end{array}$ & $\begin{array}{l}6 \\
2 \\
3 \\
0 \\
3\end{array}$ & $\begin{array}{l}5 \\
1 \\
2 \\
1 \\
1\end{array}$ & $\begin{array}{l}5 \\
0 \\
1 \\
0 \\
1\end{array}$ & $\begin{array}{l}3 \\
0 \\
0 \\
0 \\
0\end{array}$ & $\begin{array}{l}6 \\
1 \\
1 \\
1 \\
0\end{array}$ & $\begin{array}{l}8 \\
1 \\
3 \\
3 \\
0\end{array}$ & $\begin{array}{r}33 \\
5 \\
10\end{array}$ \\
\hline 2 & - & $\begin{array}{l}\text { No. of ewes } \\
\text { Oestrus } \\
\text { Ovulation } \\
\text { No. of } \mathrm{CL}-1 \\
\quad\end{array}$ & $\begin{array}{l}5 \\
1 \\
5 \\
5 \\
0\end{array}$ & $\begin{array}{l}5 \\
2 \\
4 \\
3 \\
1\end{array}$ & $\begin{array}{l}5 \\
3 \\
4 \\
4 \\
0\end{array}$ & $\begin{array}{l}3 \\
1 \\
3 \\
1 \\
2\end{array}$ & $\begin{array}{l}3 \\
0 \\
2^{*} \\
1 \\
1\end{array}$ & $\begin{array}{l}5 \\
2 \\
5 \\
5 \\
0\end{array}$ & $\begin{array}{r}26 \\
9 \\
23\end{array}$ \\
\hline 2 & + & $\begin{array}{l}\text { No. of ewes } \\
\text { Oestrus } \\
\text { Ovulation } \\
\text { No. of CL-1 }\end{array}$ & $\begin{array}{l}6 \\
5 \\
6 \\
4 \\
2\end{array}$ & $\begin{array}{l}5 \\
1 \\
5 \\
4 \\
1\end{array}$ & $\begin{array}{l}5 \\
1 \\
4 \\
1 \\
3\end{array}$ & $\begin{array}{l}3 \\
1 \\
3 \\
2 \\
1\end{array}$ & $\begin{array}{l}6 \\
2 \\
6 \\
6 \\
0\end{array}$ & $\begin{array}{l}8 \\
4 \\
8 \\
8 \\
0\end{array}$ & $\begin{array}{l}33 \\
14 \\
32\end{array}$ \\
\hline
\end{tabular}

* The third animal was not checked.

Seven of the 8 ewes mated 2 days after sponge withdrawal returned to oestrus 17 days later; corpora lutea were not observed on the ovaries of the other ewe around Day 6 , indicating that all 8 matings were infertile. None of the treatments led to fertility.

The examination of the ovaries of each sheep before the insertion of progestagen sponges indicated that ewes in the flock were anoestrous. Fresh, red, corpora lutea were totally absent; a very pale pink structure was observed on one ovary of 2 sheep ( 1 in Group A, 1 in Group M), indicating that ovarian activity had progressed beyond the stage of follicular development but the structures were quite atypical of the corpus luteum of the oestrous cycle. Both of these sheep were given LH-RH agonist and both ovulated.

LH-RH agonist induced the release of LH as shown by the plasma concentrations of LH $6 \mathrm{~h}$ later: this was $>18 \mathrm{ng} / \mathrm{ml}$ in all 33 treated ewes compared with $<6 \mathrm{ng} / \mathrm{ml}$ in all 26 untreated ewes. Agonist treatment did not, however, affect the proportion of ewes which either showed oestrus or ovulated or the proportion of twin ovulations.

Of the 59 ewes 23 showed oestrus, approximately 19 days after sponge withdrawal (i.e. the duration of one oestrous cycle after the time of oestrus typical of a cyclic ewe). When ovaries were examined for the third time by laparoscopy, about 25-33 days after sponge withdrawal, only 3 animals were found not to have ovulated (Table 1). However, the distribution of ewes presumed to have ovulated around Day 19 was not affected by the treatment, nor was the proportion of ewes which showed oestrus, when account was taken of the previous presence of a corpus luteum.

Treatment with antisera did not affect the resumption of cyclic reproductive function in the ewe, but it did affect the number of eggs shed given that they ovulated. All 6 control ewes had only one corpus luteum each whereas 8 of the 14 treated ewes that ovulated had twin ovulations (the difference is statistically significant, $P<0.05$, Fisher's exact test). With few animals ovulating, the numbers per group were too small for differences in the incidence of twin ovulations to be detected 
among treatments. The mean ovulation rate of treated ewes dropped from the 1.6 eggs observed 11 days after treatment with antisera to 1.25 at the second period of ovulation (11 of 42 had twin ovulations); all 13 control ewes again shed only 1 egg (difference, Fisher's exact test, $P<0.05$ ).

The function of the corpora lutea of all 20 ewes with corpora lutea in the first possible oestrous cycle was considered in terms of the concentration of progesterone on Days 7 and 13 . Using $1 \mathrm{ng} / \mathrm{ml}$ of plasma as a threshold, all 7 control ewes that were not recorded as having ovulated were below this threshold on both days; 2 were between 0.5 and $1 \mathrm{ng} / \mathrm{ml}$ on Day 13 . The 6 control ewes with a single ovulation all had progesterone values of $\geqslant 1: \mathrm{ng} / \mathrm{ml}$ on Day 13. The treated ewes were less uniform: 13 of the 14 recorded as having ovulated had high progesterone levels on Day $13(>1.0$ $\mathrm{ng} / \mathrm{ml}$ ) or on both days, in the 14 th ewe the concentration was low on both occasions $(<0.5 \mathrm{ng} / \mathrm{ml})$. The 5 sheep with high progesterone $(>1.0 \mathrm{ng} / \mathrm{ml})$ on both days were all in Groups $A$ or $E_{1}$. Of the 32 treated ewes not known to have ovulated, 28 had low progesterone on both occasions, 2 of the 4 remaining had high progesterone on Day 7, one on Day 3 and the other on both days. In 5 of the treated sheep, therefore, the relationship between the observation of $C L$ and the measurement of progesterone was anomalous.

\section{Discussion}

The steroid antisera treatments did not affect the incidence of oestrus or ovulation in the present sheep. Hence, they did not modify the feedback equilibria between gonadal steroid production and gonadotrophin release to an extent sufficient for the ewes to escape from the high sensitivity to oestrogen negative feedback postulated to underlie anoestrus (Legan et al., 1977). However, that the treatments did modify these equilibria is demonstrated by the increased number of CL observed on the ovaries of treated sheep which did ovulate. Indeed, the increase in ovulation rate (from 1.0 to 1.6) was the same as that observed during the breeding season (from 1.3 to 1.9) when similar doses of antisera were given (Land et al., 1982). Such a similarity of response implies that the equilibria controlling ovulation rate, as distinct from those controlling the occurrence of ovulation, are little affected by season; at the least the present results indicate that there is no continuity of the scales underlying the occurrence of ovulation on the one hand and the number of eggs shed, given that ovulation takes place, on the other.

The ovulation induced during normal anoestrus was followed by the establishment of a functional corpus luteum in all but one of the 20 ewes which ovulated in the first potential oestrous cycle after sponge withdrawal. By contrast functional corpora lutea were observed in only 3 of 5 ewes (Haresign \& Lamming, 1978) or 0 of 9 ewes (McNeilly \& Land, 1980) when ovulation was induced by LH-RH without progesterone pretreatment. The proportion of ewes ovulating was, however, lower in the present study-10 of 33 treated with LH-RH compared to all 5 of the ewes studied by Haresign \& Lamming (1978) and 9 of the 19 of McNeilly \& Land (1980).

In the present study all but 3 of the 38 ewes which were examined during the second potential cycle were found to have ovulated without any further treatment. The characterization of the stimulus for ovulation by the time of the second potential oestrous cycle is beyond the scope of the present experiment, but the observation itself corresponds to that of Purser (1973) of a small group of ewes which respond to the introduction of a ram by showing oestrus for the first time $36-40$ or 52-56 rather than 21 days later. At the time it was considered that such extended intervals may follow a series of silent ovulations at 21 and 38 as well as the usual 6 days (Purser, 1973) but this possibility was not tested. In the present experiment both the progesterone and laparoscopy data showed that the ewes did not ovulate on the first occasion. Both observations could be explained if the occurrence of ovulation in some ewes stimulated ovulation in others.

The persistence of the effect of the sera on the number of eggs shed through to the later ovulation when the treated sheep shed 0.25 eggs more than controls is similar to the effect observed in the breeding season (Land et al., 1982). It is also compatible with the estimate of around 14 days for the 
half-life, in passively immunized sheep, of antibodies similar to those used in this experiment (Pathiraja, 1982).

We thank G. Baxter and R. D. Preece for technical assistance; J. Bracken and staff at Blythbank for the care of the animals; Dr A. S. McNeilly for the measurement of progesterone; Janet Forster for statistical analyses; the NIAMDD and Dr M. Justisz for purified hormone preparations; and Dr J. Sandow (Hoechst A.G.) for LH-RH agonist.

\section{References}

Abraham, G.E. (1975) Chracterization of anti-steroid antisera. In Steroid Immunoassay, pp. 67-78. Eds E. H. D. Cameron, S. G. Hillier \& K. Griffiths. Alpha Omega Publishing Ltd, Cardiff.

Carr, W.R. \& Land, R.B. (1975) Plasma luteinizing hormone levels and testis diameter of ram lambs of different breeds. J. Reprod. Fert. 42, 325-333.

Haresign, W. \& Lamming, G.E. (1978) Comparison of LH release and luteal function in cyclic and LH-RH treated anoestrous ewes pretreated with PMSG or oestrogen. J. Reprod. Fert. 52, 349-353.

Land, R.B., Carr, W.R., McNeilly, A.S. \& Preece, R.D. (1980) Plasma FSH, LH, the positive feedback of oestrogen, ovulation and luteal function in the ewe given bromocriptine to suppress prolactin during seasonal anoestrus. J. Reprod. Fert. 59, 73-78.

Land, R.B., Morris, B.A., Baxter, G., Fordyce, M. \& Forster, J. (1982) The improvement of sheep fecundity by treatment with antisera to gonadal steroids. $J$. Reprod. Fert. 66, 625-634.

Legan, S., Karsch, F.J. Foster, D.L. (1977) The endocrine control of seasonal reproductive function in the ewe: a marked change in response to the negative feedback action of estradiol on luteinizing hormone. Endocrinology 100, 818-824.

McNeilly, A.S. \& Land, R.B. (1980) Effect of suppression of plasma prolactin on ovulation, plasma gonadotrophin and corpus luteum function in $\mathrm{LH}-\mathrm{RH}$ treated anoestrous ewes. J. Reprod. Fert. 56, 601-609.

McNeilly, A.S., Hunter, M., Land, R.B. \& Fraser, H.M. (1981) Inadequate corpus luteum function after the induction of ovulation in anoestrous ewes by $\mathrm{LH}-\mathrm{RH}$ or an LH-RH agonist. J. Reprod. Fert. 63, 137-144.

McNeilly, A.S., O'Connell, M. \& Baird, D.T. (1982) Induction of ovulation and normal luteal function by pulsed injections of LH in anestrous ewes. Endocrinology 110, 1292-1299.

Pathiraja, N. (1982) Physiological basis of genetic variation in ovulation rate. Ph.D. thesis, University of Edinburgh.

Purser, A.F. (1973) Variation in date of onset of the breeding season in sheep. Anim. Breed. Res. Org. Rep. H.M.S.O. 